\title{
PENERAPAN ANALISIS KESESUAIAN LAHAN UNTUK PENGEMBANGAN TANAMAN JANGGELAN DI KABUPATEN PACITAN
}

\author{
Supriyadi ${ }^{11}$, Joko Winarno ${ }^{2)}$ dan MMA. Retno R. ${ }^{3)}$ Sumani ${ }^{4)}$ \\ ${ }^{1,2,3,4)}$ Program Studi IImu Tanah, FP UNS
}

\begin{abstract}
ABSTRAK
Kesesuaian lahan untuk penggunaan tertentu biasanya dievaluasi dengan menggunakan karakteristik lahan atau kualitas lahan. Kesesuaian lahan sangat penting untuk menentukan keberhasilan produksi suatu tanaman. Tanaman janggelan merupakan komoditas unggulan yang potensial untuk dikembangkan. Peluang teknologi dan inovasi pengembangan tanaman janggelan sangat terbuka luas, baik sebagai sumber bahan pangan, biofarmaka, industri, maupun perdagangan. Tanaman janggelan selama ini telah dipasarkan sampai keluar negeri yaitu ke Thailand, Vietnam, dan China dalam bentuk kering. Namun selama ini, tanaman janggelan belum banyak dikembangkan dan hanya ditanaman sebagai tanaman sampingan dalam agroforestri. Tujuan kegiatan ini adalah pengembangan tanaman janggelan berdasarkan analisis kesesuaian lahan di Kabupaten Pacitan dan meningkatkan produksi cincau hitam di kabupaten Pacitan.
\end{abstract}

Kata kunci : janggelan, kesesuaian lahan, Pacitan.

\begin{abstract}
Land suitability for particular uses is usually evaluated using land characteristics or land quality. Land suitability is crucial to determining the success of a plant's production. Janggelan plants are potential commodities that are potential to be developed. Technological opportunities and innovations in the development of Janggelan are very wide open, both as a source of food, biopharmaceutical, industrial, and trade. The cultivated land has been exported to Thailand, Vietnam and China in dry form. However, during this time, janggelan plants have not been developed and only planted as side crops in agroforestry. The purpose of this activity is the development of janggelan plant based on land suitability analysis in Pacitan Regency and increase the production of grass jelly in Pacitan regency.
\end{abstract}

Keywords : janggelan, land suitability, Pacitan. 


\section{PENDAHULUAN}

\section{Latar Belakang}

Jumlah penduduk yang semakin bertambah dengan begitu pesat saat ini akan dapat menyebabkan munculnya berbagai masalah seperti masalah sosial dan lingkungan. Sedangkan dengan meningkatnya kebutuhan pokok masyarakat akan mendorong manusia untuk mengeksploitasi sumber daya alam secara berlebihan. Hutan dan tanah sebagai penopang pokok hutan akan mengalami degradasi di berbagai segi, termasuk daya dukungnya dalam memenuhi kebutuhan masyarakat.

Tanah sangat berperan dalam kehidupan karena tanah mempunyai beberapa fungsi yang sangat pokok antara lain sebagai tempat tumbuhnya tanaman, sebagai sumber unsur hara tanaman, penyedia air dan udara untuk tanaman yang ada di dalam ruang pori tanah. Manusia sangat bergantung pada tanah untuk bertahan hidup dan tanah membutuhkan manusia untuk menjaga kelestariannya.
Rekomendasi pengelolaan dan evaluasi kesesuaian lahan diperlukan survei tanah untuk mendapat data lahan dengan mengambil sampelsampel tanah pada lokasi tujuan sehingga dapat mengklasifikasi, menganalisis dan memetakan tanah serta mengelompokkan tanah-tanah yang sama atau hampir sama sifatnya ke dalam satuan peta tanah tertentu.

Data yang didapat dalam survei tanah dapat menginterpretasikan keadaan sebenarnya di lapangan untuk dikombinasikan dengan keadaan dan kesesuaian tanaman kakao, sehingga dapat dihasilkan rekomendasi macam pengelolaan dan evaluasi kesesuaian lahan pada lahan tersebut. Salah satu hal pokok yang diperlukan untuk melakukan perencanaan secara menyeluruh yaitu tersedianya informasi faktor fisik lingkungan yang meliputi sifat dan potensi lahan. Keterangan ini dapat diperoleh antara lain melalui kegiatan survei tanah yang diikuti dengan pengevaluasian lahan Kesesuaian lahan untuk penggunaan tertentu biasanya 
dievaluasi dengan menggunakan karakteristik lahan atau kualitas lahan. Karakteristik lahan merupakan kelengkapan lahan itu sendiri, yang dapat dihitung atau diperkirakan seperti curah hujan, tekstur tanah dan ketersediaan air, sedangkan kualitas lahan lebih merupakan sifat tanah yang lebih kompleks, seperti kesesuaian kelembaban tanah, ketahanan terhadap erosi dan bahaya banjir (Nasution 2005).

Kesesuaian lahan sangat

penting untuk menentukan

keberhasilan produksi suatu tanaman.

Tanaman janggelan merupakan komoditas unggulan yang potensial untuk dikembangkan. Peluang teknologi dan inovasi pengembangan tanaman janggelan sangat terbuka luas, baik sebagai sumber bahan pangan, biofarmaka, industri, maupun perdagangan. Sangat penting untuk menumbuh kembangkan potensipotensi unggulan daerah yang telah kita miliki seperti tanaman janggelan dalam upaya meningkatkan perekonomian rakyat dan kesejahteraan masyarakat. Pasalnya tanaman jannggelan telah dipasarkan sampai keluar negeri yaitu ke Thailand, Vietnam, dan China dalam bentuk kering. Namun selama ini, tanaman janggelan belum banyak dikembangkan dan hanya ditanaman sebagai tanaman sampingan dalam agroforestri. Maka dari itu, LPPM UNS mengusulkan kegiatan Penerapan Analisis Kesesuaian Lahan Untuk Pengembangan Tanaman Janggelan Di Kabupaten Pacitan.

\section{Landasan Teori}

Survei tanah merupakan istilah umum untuk penyelidikan tanah sistematik dilapangan di laboratorium deskripsi klasifikasi pemetaan jenis tanah penafsiran (interpretasi) tanah menurut kesesuaian tanah bagi tanaman rumput pohon serta perilaku tanah dibawah pemakaian atau perlakuan untuk produktivitas dalam pengelolaan yang berbeda-beda (Hardjowigeno, 2003.). 
Menurut Foth (1991), survei (Abdullah 1993). Berdasarkan intensitas tanah adalah proses mempelajari dan pengamatannya, survei tanah memetakan permukaan bumi dalam dibedakan atas 6 tingkatan survei, yaitu pola unit yang disebut tipe tanah. : bagan, eksplorasi, tinjau, semi detail, Hardjowigeno (1987) mengemukakan, detail dan sangat detail tujuan dari survei tanah adalah Satuan tanah yang digunakan mengklasifikasi, menganalisis, dalam peta tanah tertentu, dapat memetakan tanah dan berupa jenis, macam, rupa, seri tanah mengelompokkan tanah-tanah yang menurut kategori dalam system sama atau hampir sama sifatnya ke klasifikasi tanah. Jenis tanah dalam satuan peta tanah tertentu. mempunyai persamaan horizon-horison Survei tanah merupakan pekerjaan penciri dengan gejala-gejala pengumpulan data kimia, fisik, dan pengikutnya dan terbentuk pada proses biologi di lapangan maupun di pembentukan tanah yang sama. Macam laboratorium, dengan tujuan tanah mempunyai persamaan horizon pendugaan penggunaan lahan umum penciri atau lapisan sedalam kurang maupun khusus. Suatu survei tanah lebih $50 \mathrm{~cm}$, terutama mengenai warna, baru memiliki kegunaan yang tinggi jika sifat horizon tambahan atau horizon teliti dalam memetakannya. Hal itu peralihannya. Rupa tanah dalam berarti : 1) Tepat mencari site yang pembagian macam tanah dibedakan representatif, tepat meletakkan site atas dasar perbedaan tekstur dan pada peta yang harus didukung oleh drainase tingkat rupa. Seri tanah adalah peta dasar yang baik, 2) Tepat segolongan tanah yang terbentuk dari dalam mendeskripsi profilnya atau bahan induk yang sama, mempunyai benar dalam menetapkan sifat-sifat sifat dan susunan horizon sama morfologinya, 3) Teliti dalam (Darmawijaya 1990).

mengambil contoh, dan 4) Benar Satuan peta tanah (soil menganalisisnya di laboratorium mapping unit) tersusun dari kesatuan 3 
satuan yaitu : 1) satuan tanah, 2) satuan bahan induk beri gambar jelas tentang tanah dan wilayah dan 3) satuan wilayah. Sifat-sifat dari masingmasing satuan peta secara singkat dicantumkan dalam legenda, sedang uraian lebih detail dicantumkan dalam laporan survei tanah yang selalu menyertai peta tanah tersebut. Disamping itu dilakukan interpretasi kemampuan tanah dari masing-masing satuan peta tanah untuk penggunaanpenggunaan tanah tertentu (Abdullah 1993).

Satuan peta tanah (soil mapping unit) tersusun dari unsurunsur yang pada dasarnya merupakan kesatuan dari tiga satuan, ialah satuan tanah, satuan bahan induk dan satuan wilayah. Perbedaan satuan peta dalam berbagai kategori peta tanah terletak pada ketelitian masing-masing unsure satuan petanya. Penggunaan tiga unsur dimaksudkan untuk dapat memberi gambaran yang jelas dari suatu wilayah tentang keadaan tanah dan wilayahnya (Darmawijaya 1990).
Evaluasi lahan merupakan suatu proses penilaian suatu lahan sehingga sesuai dengan kondisinya pada penggunaan-penggunan tertetentu. Evaluasi lahan berguna untuk mengetahui potensi atau kemampuan lahan bagi penggunaan lahan tertentu. Misalnya bagi tanaman, pariwisata, pemukiman dll. Apabila potensi lahan ini diketahui secara dini, perencanaan untuk tata guna lahan akan diharapkan akan memberikan dampak berkelanjutan bagi lahan tersebut (Hardjowigeno 2003).

Evaluasi lahan adalah suatu proses penilaian sumber daya lahan untuk tujuan tertentu dengan menggunakan suatu pendekatan atau cara yang sudah teruji. Hasil evaluasi lahan akan memberikan informasi dan/atau arahan penggunaan lahan sesuai dengan keperluan (Watanabe, 2008). Evaluasi lahan merupakan suatu proses analisis untuk mengetahui potensi lahan untuk penggunaan tertentu yang berguna untuk membantu perencanaan penggunaan 
dan pengelolaan lahan. Evaluasi lahan meliputi interpretasi data fisik kimia tanah, potensi penggunaan lahan sekarang dan sebelumnya yang bertujuan untuk memecahkan masalah jangka panjang terhadap penurunan kualitas lahan yang disebabkan oleh pengunaannya saat ini, memperhitungkan dampak penggunaan lahan, merumuskan alternatif penggunaan lahan dan mendapatkan cara pengelolaan yang lebih baik (Nasution 2005).

Tujuan umum kegiatan pengabdian adalah pengembangan tanaman janggelan berdasarkan analisis kesesuaian lahan di Kabupaten Pacitan. Tujuan khususnya adalah meningkatkan produksi cincau hitam di kabupaten Pacitan sehingga menjadi produk ungulan daerah Pacitan. Permasalahan yang dihadapi adalah budidaya janggelan yang belum memperhatikan keseuaian lahan tanaman janggelan sehingga potensi tanaman janggelan belum dimanfaatkan secara maksimal

\section{METODE PENGABDIAN}

Kegiatan pengabdian ni dilaksanakan bersama 7 UKM Petani Janggelan di Kabupaten Pacitan. UKM tersebut terletak di 4 kecamatan berbeda, yaitu kecamatan Arjosari, Kebonagung, Tulakan, dan Ngadirojo. Analisis pupuk dilaksanakan di Laboratorium Kimia dan Kesuburan Tanah, Fakultas Pertanian, Universitas Sebelas Maret Surakarta. Penelitian dilaksanakan mulai bulan Mei sampai dengan bulan Oktober 2015. Metode pengabdian ini dilakukan dengan memberikan pelatihan kepada petani dalam menentukan lahan untuk budidaya tanaman janggelan. Metode yang digunakan meliputi: diskusi, pelatihan dan pendampingan (kelompok dan individu). Langkahlangkah pelaksanaan disajikan pada Tabel 1. Secara umum peran dan partisipasi mitra dalam kegiatan IPM disajikan pada Tabel 2. 
Tabel 1. Pola dan Metode implemntasi Iptek Pemberdayaan Masyarakat

\begin{tabular}{|l|l|l|}
\hline \multicolumn{1}{|c|}{ Kegiatan } & & \multicolumn{3}{|c|}{ Tahapan kegiatan } \\
\hline Evaluasi lahan & $:$ & $\begin{array}{l}\text { Survey lahan, Analisis dan evaluasi lahan Matching } \\
\text { persyaratan tanaman janggelan, Peta arahan budidaya } \\
\text { tanaman janggelan, dan Penanaman tanaman janggelan } \\
\text { berdasar kesesuaian lahan }\end{array}$ \\
\hline $\begin{array}{l}\text { Pengembangan } \\
\text { pemasaran }\end{array}$ & $\begin{array}{l}\text { Diskusi Tim dengan gapoktan tentang kondisi } \\
\text { manajemen produksi yang sudah ada } \\
\text { (kelebihan/kekurangan), Tim melakukan analisis } \\
\text { kebutuhan manajemen pemasaran, termasuk kebutuhan } \\
\text { teknologi informatika, Tim membuat desain leaflet } \\
\text { dan kantong kemasan sebagai media promosi, dan } \\
\text { Membuat website dan email sebagai media promosi } \\
\text { antar pulau dan luar negeri }\end{array}$ \\
\hline
\end{tabular}

Tabel 2. Peran dan partisipasi mitra dan Gapoktan

\begin{tabular}{|l|l|l|}
\hline \multicolumn{1}{|c|}{ Institusi } & \multicolumn{1}{c|}{ Peran } & \multicolumn{1}{c|}{ Manfaat yang diperoleh } \\
\hline Pemerintah desa , & ljin kegiatan & Kegiatan berjalan lancer \\
\hline Mitra & Peserta aktif kegiatan & Pemecahan masalah \\
\hline Balitbang Kab. Pacitan & Mediator & $\begin{array}{l}\text { Memfasilitasi kegiatan } \\
\text { dilapangan }\end{array}$ \\
\hline Masyarakat & Konsumen & Kesejahteraan \\
\hline
\end{tabular}




\section{HASIL, PEMBAHASAN DAN DAMPAK}

Tanaman cincau hitam

menghendaki lokasi penanaman yang suhunya berkisar 20 ㅇ- $30^{\circ} \mathrm{C}$, dengan curah hujan minimal 3000 mm/tahun. Tanaman ini sebaiknya ditanam pada ketinggian diatas $100 \mathrm{~m}$ dpl, dan optimal pada ketinggian 200 - 800 meter dpl. Kondisi tanah yang harus dipenuhi agar tanaman dapat tumbuh dengan baik adalah tanah yang gembur seperti lempung berpasir dengan kemiringan tanah 20-30\%. Evaluasi kesesuaian lahan secara aktual merupakan hasil evaluasi pada saat dilakukan survai di lapangan (menurut kondisi yang ada) sebelum dilakukan input teknologi. Penilaian kelas kesesuaian lahan didasarkan pada kriteria yang dikeluarkan oleh FAO (1976). Hasil analisis kesesuaian lahan aktual tanaman kakao masing-masing SPL dan klaster dapat dilihat pada Tabel 3.

Tabel 3 menunjukkan kesesuaian lahan aktual pada Nawangan dapat digolongkan ke dalam kelas sangat sesuai (S1). Hasil klasifikasi kesesuaian lahan tanaman Janggelan menunjukkan bahwa pada SPL 1 memiliki faktor pembatas Kemiringan,kedalaman efektif, KTK, drainase, unsur hara. SPL 2 memiliki faktor pembatas kedalaman efektif, lereng, drainase, unsur hara. Selanjutnya SPL 3 hanya memiliki faktor pembatas unsur hara. SPL 4 memiliki faktor pembatas KTK, unsur hara. SPL 5 dengan kedalaman efektif, drainase.

Hasil analisis kesesuaian lahan aktual pada daerah Tulakan digolongkan ke dalam kelas sesuai (S2). Hasil klasifikasi menunjukkan bahwa pada SPL 1 memiliki faktor pembatas Curah Hujan, Kedalaman efektif, lereng, KTK, unsur hara. SPL 2 memiliki faktor pembatas kedalaman efektif dan bahan organik. SPL 3 memiliki faktor pembatas kedalaman efektif, lereng, bahan organik dan unsur hara. SPL 4 hanya memiliki faktor pembatas curah hujan, Kondisi tanah, Kedalaman efektif, salinitas, selanjutnya SPL 5 dengan curah hujan, Kedalaman efektif, lereng, unsur hara. 
Hasil analisis kesesuian lahan faktor pembatas kemiringan lereng, aktual Kebonagung juga digolongkan ke kedalaman, unsur hara. dalam kelas sesuai (S2). Hasil klasifikasi menunjukkan bahwa pada SPL 1 memiliki faktor pembatas kedalaman efektif, lereng dan unsur hara. SPL 2 dengan faktor pembatas kedalaman efektif dan lereng. SPL 3 memiliki faktor pembatas kedalaman efektif dan unsur hara, sedangkan SPL 4 memiliki faktor pembatas ketmiringanlereng, kedalaman efektif dan unsur hara selanjutnya SPL 5 memiliki faktor pembatas ketinggian, bulan kering, kedalaman efektif, pH dan unsur hara.

Hasil analisis kesesuian lahan aktual Wonokarto juga digolongkan ke dalam kelas sangat sesuai (S1) Hasil klasifikasi menunjukkan bahwa pada SPL 1 memiliki faktor pembatas curah hujan, Kemiringan, kedalaman efektif, drainase. SPL 2 dengan faktor pembatas Kedalaman efektif, lereng. SPL 3 memiliki faktor pembatas Kemiringan, drainase, unsur hara SPL 4 memiliki faktor pembatas kemiringan lereng, kedalaman efektif, dan SPL 5 memiliki 
Tabel 3. Kesesuaian Lahan Janggelan (Mesona palustri) beberapa daerah di Kabupaten Pacitan

\begin{tabular}{|c|c|c|c|c|c|c|c|c|}
\hline \multirow{2}{*}{$\begin{array}{l}\text { No } \\
\text { SPL }\end{array}$} & \multicolumn{4}{|c|}{ Kesesuaian Lahan Aktual } & \multicolumn{4}{|c|}{ Faktor Pembatas } \\
\hline & Nawangan & Tulakan & $\begin{array}{l}\text { Kebon } \\
\text { Agung }\end{array}$ & Wonokarto & Nawangan & Tulakan & Kebon Agung & Wonokarto \\
\hline \multirow{2}{*}{1} & S1 & $\mathrm{S} 2$ & S1 & $\mathrm{S} 2$ & \multirow{2}{*}{$\begin{array}{l}\text { Kemiringan, kedala } \\
\text { man efektif, } \\
\text { drainase, unsur } \\
\text { hara }\end{array}$} & \multirow{2}{*}{$\begin{array}{l}\text { Curah hujan, } \\
\text { kedalaman efektif, } \\
\text { lereng, KTK, unsur } \\
\text { hara }\end{array}$} & \multirow{2}{*}{$\begin{array}{l}\text { Kedalaman efektif, } \\
\text { lereng, unsur hara }\end{array}$} & \multirow{2}{*}{$\begin{array}{l}\text { Curah hujan, } \\
\text { kemiringan, } \\
\text { kedalaman } \\
\text { efektif, drainase }\end{array}$} \\
\hline & $r, f, n$ & $r, f, n$ & $r, n$ & $c, r, f$ & & & & \\
\hline \multirow{2}{*}{2} & S1 & S2 & S1 & S1 & \multirow{2}{*}{$\begin{array}{l}\text { Kedalaman efektif, } \\
\text { lereng, drainase, } \\
\text { unsur hara }\end{array}$} & \multirow{2}{*}{$\begin{array}{l}\text { Kedalaman efektif, } \\
\text { bahan organik }\end{array}$} & \multirow{2}{*}{$\begin{array}{l}\text { Kedalamanan } \\
\text { efektif, lereng }\end{array}$} & \multirow{2}{*}{$\begin{array}{l}\text { Kedalaman } \\
\text { efektif, lereng }\end{array}$} \\
\hline & $r, f, n$ & $r, f$ & $\mathrm{R}$ & $r$ & & & & \\
\hline \multirow{2}{*}{3} & S1 & S1 & S2 & S1 & \multirow{2}{*}{ Unsur hara } & \multirow{2}{*}{$\begin{array}{l}\text { Kedalaman efektif, } \\
\text { lereng, bahan } \\
\text { organik, unsur hara }\end{array}$} & \multirow{2}{*}{$\begin{array}{l}\text { Kedalaman efektif, } \\
\text { unsur hara }\end{array}$} & \multirow{2}{*}{$\begin{array}{l}\text { Kemiringan, } \\
\text { drainase, unsur } \\
\text { hara }\end{array}$} \\
\hline & $\mathrm{n}$ & $r, f, n$ & $r, n$ & $r, f, n$ & & & & \\
\hline \multirow{2}{*}{4} & S1 & $\mathrm{S} 2$ & S1 & S1 & \multirow{2}{*}{ KTK, unsur hara } & \multirow{2}{*}{$\begin{array}{l}\text { Curah hujan, kondisi } \\
\text { tanah, kedalaman } \\
\text { efektif, salinitas }\end{array}$} & \multirow{2}{*}{$\begin{array}{l}\text { Kemiringan lereng, } \\
\text { kedalaman efektif, } \\
\text { unsur hara }\end{array}$} & \multirow{2}{*}{$\begin{array}{l}\text { Kemiringan } \\
\text { lereng, } \\
\text { kedalaman efektif }\end{array}$} \\
\hline & $f, n$ & $c, r, f$ & $r, n$ & $r$ & & & & \\
\hline \multirow[b]{2}{*}{5} & S1 & $\mathrm{S} 2$ & S2 & S1 & \multirow{2}{*}{$\begin{array}{l}\text { Kedalaman efektif, } \\
\text { drainase }\end{array}$} & \multirow{2}{*}{$\begin{array}{l}\text { Curah hujan, } \\
\text { kedalamman efektif, } \\
\text { lereng, unsur hara }\end{array}$} & \multirow{2}{*}{$\begin{array}{l}\text { Ketinggian tempat, } \\
\text { curah hujan, } \\
\text { kedalaman efektif, } \\
\text { pH, unsur hara }\end{array}$} & \multirow{2}{*}{$\begin{array}{l}\text { Kemiringan } \\
\text { lereng, } \\
\text { kedalaman, unsur } \\
\text { hara }\end{array}$} \\
\hline & $r, f$ & $c, r, n$ & $c, r, f, n$ & r & & & & \\
\hline
\end{tabular}

$\mathrm{a}=$ elevasi (ketinggian), c = curah hujan (bulan kering, rata-rata hujan tahunan), $r=$ kondisi tanah (drainase, tekstur, kedalaman efektif dan lereng), $\mathrm{f}=$ sifat kimia tanah (KTK, pH dan C-organik, salinitas), $\mathrm{n}=$ unsur hara ( $\mathrm{N}$-total, $\mathrm{P}$ tersedia, $\mathrm{K}$ tersedia), $\mathrm{S} 2=\mathrm{cukup}$ sesuai, $\mathrm{S} 3=$ sesuai marginal. 
Kesesuaian lahan aktual pada Nawangan dapat digolongkan ke dalam kelas sangat sesuai (S1). Hasil klasifikasi kesesuaian lahan tanaman Janggelan menunjukkan bahwa pada SPL 1 memiliki faktor pembatas kemiringan,kedalaman efektif, KTK, drainase, unsur hara. SPL 2 memiliki faktor pembatas kedalaman efektif, lereng, drainase, unsur hara. Selanjutnya SPL 3 hanya memiliki faktor pembatas unsur hara. SPL 4 memiliki faktor pembatas KTK, unsur hara. SPL 5 dengan kedalaman efektif, drainase. Kesesuaian lahan aktual pada daerah Tulakan digolongkan ke dalam kelas sesuai (S2). Hasil klasifikasi menunjukkan bahwa pada SPL 1 memiliki faktor pembatas Curah Hujan, Kedalaman efektif, lereng, KTK, unsur hara. SPL 2 memiliki faktor pembatas kedalaman efektif dan bahan organik. SPL 3 memiliki faktor pembatas kedalaman efektif, lereng, bahan organik dan unsur hara. SPL 4 hanya memiliki faktor pembatas curah hujan, Kondisi tanah, Kedalaman efektif, salinitas, selanjutnya SPL 5 dengan curah hujan, Kedalaman efektif, lereng, unsur hara. Kesesuian lahan aktual Kebonagung juga digolongkan ke dalam kelas sesuai (S2). Hasil klasifikasi menunjukkan bahwa pada SPL 1 memiliki faktor pembatas kedalaman efektif, lereng dan unsur hara. SPL 2 dengan faktor pembatas kedalaman efektif dan lereng. SPL 3 memiliki faktor pembatas kedalaman efektif dan unsur hara, sedangkan SPL 4 memiliki faktor pembatas ketmiringan lereng, kedalaman efektif dan unsur hara selanjutnya SPL 5 memiliki faktor pembatas ketinggian, bulan kering, Kedalaman efektif, pH dan unsur hara.

Kesesuian lahan aktual Wonokarto juga digolongkan ke dalam kelas sangat sesuai (S1) Hasil klasifikasi menunjukkan bahwa pada SPL 1 memiliki faktor pembatas curah hujan, kemiringan, kedalaman efektif, drainase. SPL 2 dengan faktor pembatas kedalaman efektif, lereng. SPL 3 memiliki faktor pembatas kemiringan, drainase, unsur hara SPL 4 
memiliki faktor pembatas kemiringan lereng, kedalaman efektif, dan SPL 5 memiliki faktor pembatas kemiringan lereng, kedalaman dan unsur hara.

\section{PENUTUP}

Berdasarkan hasil yang telah dicapai maka dapat disimpulkan bahwa kelas kesesuaian lahan janggelan di beberapa daerah pengembangan tanaman janggelan, memiliki kelas sangat sesuai (S1) dan sesuai (S2), dengan beberapa faktor penghambat. baik drainase, lereng, hingga KTK dan unsur hara tanah. Perlu adanya perbaikan drainase serta, lereng agar peningkatan produksi semakin baik.

\section{UCAPAN TERIMAKASIH}

Pada kesempatan ini, penulis mengucapkan terimakasih yang besar besarnya kepada Lembaga Penelitian dan Pengabdian Kepada Masyarakat UNS, yang telah memberikan dukungan pendanaan pada kegiatan ini

\section{REFERENSI}

Abdullah. 1993. Survai Tanah dan evaluasi Lahan. Penebar Swadaya. Jakarta

Darmawijaya, Isa. 1990. Klasifikasitanah. Gadjah Mada University Press: Yogyakarta

FAO. 1976. Framework For Land Evolution. FAO Soils Bulletin. Soil Resources Manage-ment and Conservation Service Land and Water Development Division.

Foth, H. D. 1991. DasarDasarllmu Tanah.Erlangga. Jakarta. Hardjowigeno, Sarwono. 2003. Ilmu Tanah. Akademika Pressindo. Jakarta Hardjowigeno, S. 1987. IImu Tanah. Akademika Pressindo. Jakarta. Nasution A. 2005. Ilmu Kesuburan Tanah. Kanisius. Yogyakarta

Watanabe.2008. Plant litter quality and decomposition : An Historical overview in G. Cadish and K.E. Giller $\quad A B$ International, Wallingford. p. 3-33 


\section{LAMPIRAN}

Arahan Kesesuaian Lahan Janggelan di Pacitan

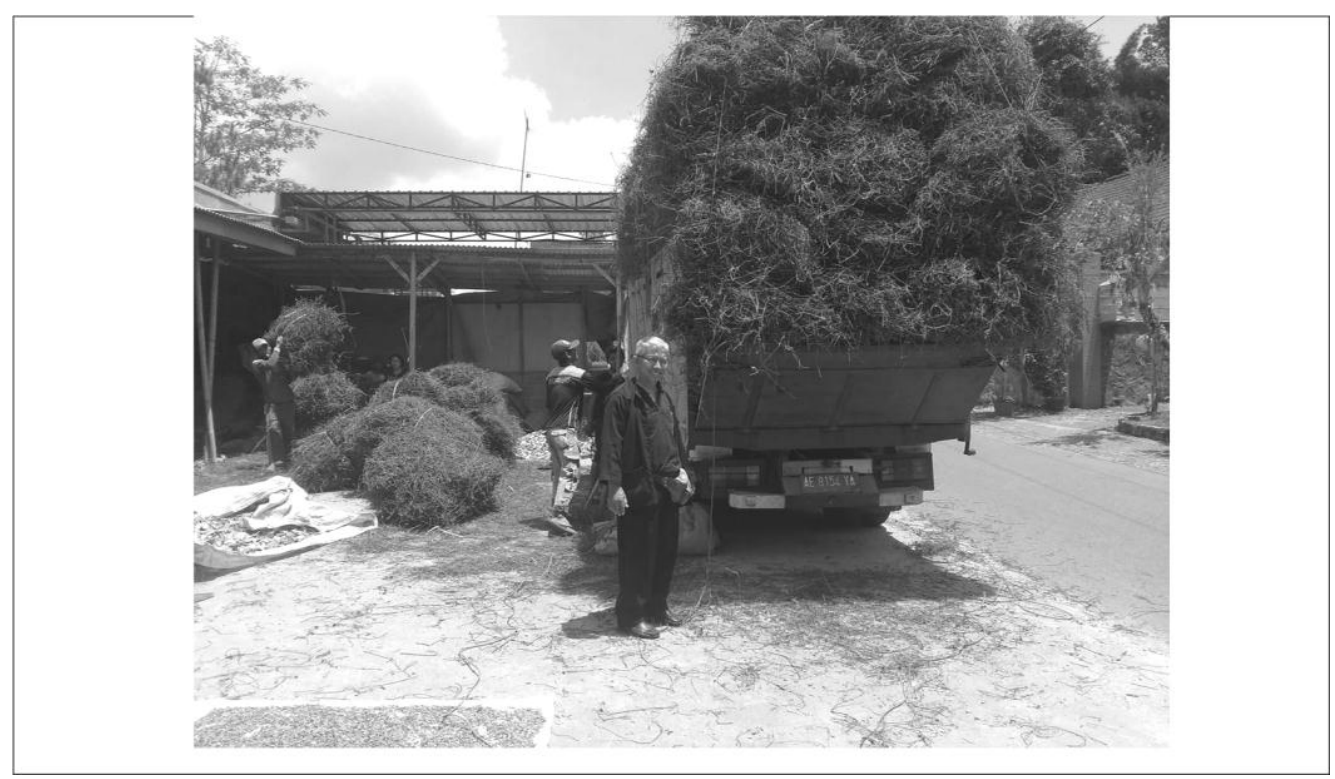

\section{Oleh :}

Dr. Ir. Supriyadi

Drs. Joko Winarno, M.Si

Dr. Ir. MMA. Retno Rosariastuti, MS

Ir. Sumani, M.Si
0012066104

0021055905

0018105907

0004076308 
Jurnal SEMAR, ISSN 2302-3937

Vol.6 No.1 Nopember 2017

\section{Peta Kesesuaian Lahan Janggelan di Pacitan}

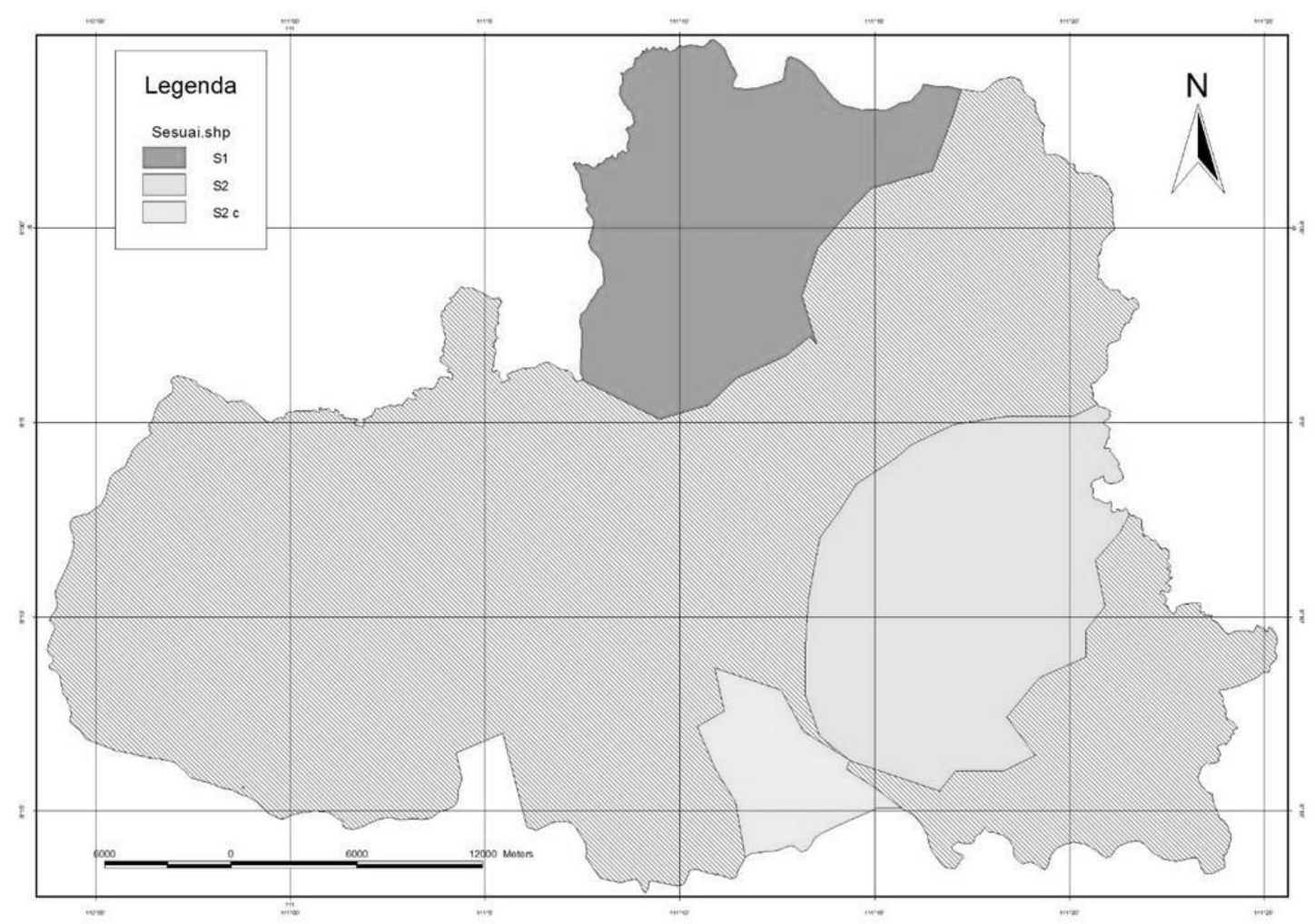


Kesesuaian lahan aktual pada Nawangan dapat digolongkan ke dalam kelas sangat sesuai (S1). Hasil klasifikasi kesesuaian lahan tanaman janggelan menunjukkan bahwa pada SPL 1 memiliki faktor pembatas kemiringan, kedalaman efektif, KTK, drainase, unsur hara. SPL 2 memiliki faktor pembatas kedalaman efektif, lereng, drainase, unsur hara. Selanjutnya SPL 3 hanya memiliki faktor pembatas unsur hara. SPL 4 memiliki faktor pembatas KTK, unsur hara. SPL 5 dengan kedalaman efektif, drainase. Kesesuaian lahan aktual pada daerah Tulakan digolongkan ke dalam kelas sesuai (S2). Hasil klasifikasi menunjukkan bahwa pada SPL 1 memiliki faktor pembatas Curah Hujan, Kedalaman efektif, lereng, KTK, unsur hara. SPL 2 memiliki faktor pembatas kedalaman efektif dan bahan organik. SPL 3 memiliki faktor pembatas kedalaman efektif, lereng, bahan organik dan unsur hara. SPL 4 hanya memiliki faktor pembatas curah hujan, kondisi tanah, kedalaman efektif, salinitas, selanjutnya SPL 5 dengan curah hujan, kedalaman efektif, lereng, unsur hara. Kesesuian lahan aktual Kebonagung juga digolongkan ke dalam kelas sesuai (S2). Hasil klasifikasi menunjukkan bahwa pada SPL 1 memiliki faktor pembatas kedalaman efektif, lereng dan unsur hara. SPL 2 dengan faktor pembatas kedalaman efektif dan lereng. SPL 3 memiliki faktor pembatas kedalaman efektif dan unsur hara, sedangkan SPL 4 memiliki faktor pembatas ketmiringan lereng, kedalaman efektif dan unsur hara selanjutnya SPL 5 memiliki faktor pembatas ketinggian, bulan kering, kedalaman efektif, $\mathrm{pH}$ dan unsur hara. Kesesuian lahan aktual Wonokarto juga digolongkan ke dalam kelas sangat sesuai (S1) Hasil klasifikasi menunjukkan bahwa pada SPL 1 memiliki faktor pembatas curah hujan, kemiringan, kedalaman efektif, drainase. SPL 2 dengan faktor pembatas kedalaman efektif, lereng. SPL 3 memiliki faktor pembatas kemiringan, drainase, unsur hara SPL 4 memiliki faktor pembatas kemiringan lereng, 
Jurnal SEMAR, ISSN 2302-3937

Vol.6 No.1 Nopember 2017

kedalaman efektif, dan SPL 5 memiliki

faktor pembatas kemiringan lereng, kedalaman dan unsur hara. 


\section{BIODATA PENELITI}

Dr. Ir. Supriyadi, M.P.

Tenaga Pendidik atau dosen di program studi Ilmu Tanah Fakultas Pertanian Universitas Sebelas Maret. Lulusan S2 Universitas Gadjah Mada Yogyakarta Tahun 1995 dan S3 Universitas Brawijaya Malang pada tahun 2001. Saat ini menjabat sebagai koordinator Pengabdian pada Masyarakat pada Unit Pengaduan dan Penjaminan Mutu Penelitian dan Pengabdian pada Masyarakat LPPM UNS. Pengalaman Penelitian 5 tahun terakhir salah satunya bertema "Pengembangan Organisme Fungsional Sebagai Biofertilizer Untuk Meningkatkan Hasil Pertanian Dan Efisiensi Masukan Produksi" (2016). Pengalaman pengabdian pada masyarakat 5 tahun terakhir diantarannya "KKN-PPM Pertanian Organik" (2012). 